Universitas Muhammadiyah Bengkulu P-ISSN: 2599-1892

Vol. 1, No. 1, Januari 2018

\title{
Tinjauan Yuridis Transaksi Jual Beli Online Menurut Undang-Undang Nomor 11 Tahun 2008 Tentang Informasi dan Transaksi Elektronik di Kota Bengkulu
}

\section{Juridical Review of Buy and Sell Transactions Online According to Law Number 11 Year 2008 regarding Information and Electronic Transactions in Bengkulu City}

\author{
Sapriandi Tanjung \\ Universitas Muhammadiyah Bengkulu, email: s.tanjung92@gmail.com
}

\begin{abstract}
ABSTRAK
Suatu perjanjian jual beli online melalui internet dianggap sah apabila memenuhi syarat subyektif dan syarat obyektif, pemenuhan atas syarat tersebut berakibat pada perjanjian yang telah dibuat menjadi sah sebagaimana diatur dalam KUHP Pasal 1320. Seiring dengan perkembangan e-commerce, semakin bertambah juga permasalahan yang timbul akibat maraknya e-commerce tersebut. Salah satu permasalahan yang timbul yaitu adanya wanprestasi yang dilakukan oleh salah satu pihak yang terlibat dalam e-commerce tersebut. Tujuan penelitian ini adalah untuk mengetahui apakah transaksi jual beli online memenuhi syarat sahnya perjanjian dan mengetahui apakah bentuk transaksi online menurut UU No. 11 Tahun 2008 tidak bertentangan dengan syarat sah suatu perjanjian. Jenis penelitian yang digunakan oleh penulis adalah penelitian empiris yang bersifat deskriptif. Penelitian hukum bersifat deskriptif merupakan penelitian yang bertujuan menggambarkan tentang sifat-sifat individu, keadaan, gejala atau kelompok tertentu atau untuk menentukan penyebaran suatu gejala dengan gejala lain dalam masyarakat. Syarat sah transaksi berdasarkan Pasal 2 Undang-Undang Nomor 11 Tahun 2008 tentang Informasi dan Transksi Elektronik ("UU ITE") adalah Undang-Undang ini berlaku untuk setiap Orang yang melakukan perbuatan hukum sebagaimana diatur dalam UndangUndang ini, baik yang berada di wilayah hukum Indonesia maupun di luar wilayah hukum Indonesia, yang memiliki akibat hukum di wilayah hukum Indonesia dan/atau di luar wilayah hukum Indonesia dan merugikan kepentingan Indonesia. Berdasarkan ketentuan ini, anak-anak yang masih di bawah umur dapat melakukan E-Commerce dan tidak memenuhi syarat subjektif dalam Pasal 1320 KUHPerdata. Oleh karena itu, kontrak dapat dibatalkan melalui seseorang yang mengajukan pembatalan di pengadilan. Masih banyak pelaku usaha yang ketika menawarkan produknya di dunia maya atau internet memberikan informasi yang kurang baik dan kurang benar sehingga konsumen tidak merasa di kecewakan karena ada upaya hukum yang bisa dilakukan oleh pembeli perdata sesuai dengan Undang-Undang No. 11 tahun 2008 tentang ITE.
\end{abstract}


Tinjauan Yuridis Transaksi Jual beli Online Menurut UU No.11 Tahun 2008

Tentang Informasi dan Transaksi Elektronik di Kota Bengkulu

\section{Abstract}

An online buying and selling agreement through the internet is considered valid if it meets the subjective requirements and objective conditions, the fulfillment of these conditions result in the agreement has been made legitimate as provided in the Criminal Code Article 1320. Along with the development of e-commerce, the more problems arise as a result rampant e-commerce. One of the problems that arises is the existence of wanprestasi done by one of the parties involved in the e-commerce. The purpose of this study is to determine whether the online sale and purchase transactions meet the terms of the validity of the agreement and find out whether the form of online transactions according to Law no. 11 of 2008 is not contradictory to the legal terms of an agreement. The type of research used by the author is descriptive empirical research. Legal research is descriptive is a study aimed at describing the nature of individuals, circumstances, symptoms or specific groups or to determine the spread of a symptom with other symptoms in society. Legal requirements of transactions under Article 2 of Law Number 11 Year 2008 on Electronic Information and Transaction ("Act on ITE") is this Act applies to any Person who commits a legal act as provided for in this Act, whether located in the territory Indonesian law as well as outside the jurisdiction of Indonesia, which has legal consequences in the jurisdiction of Indonesia and / or outside the jurisdiction of Indonesia and harms the interests of Indonesia. Under this provision, minors may perform E-Commerce and do not meet the subjective requirements of Section 1320 of the Civil Code. Therefore, the contract may be canceled through a person who filed a cancellation in court. There are still many business actors who when offering their products in cyberspace or internet provide information that is less good and less true so that consumers do not feel in disappointing because there are legal efforts that can be done by civil buyers in accordance with the Act no. 11 of 2008 on ITE.

Keywords: Buy and Sell Online, UU ITE

\section{PENDAHULUAN}

Suatu perjanjian jual beli online melalui internet dianggap sah apabila memenuhi syarat subyektif dan syarat obyektif, pemenuhan atas syarat tersebut berakibat pada perjanjian yang telah dibuat menjadi sah sebagaimana terdapat dalam Undang-Undang Hukum Perdata suatu perjanjian telah diatur dalam Pasal 1320.Perjanjian juga mengikat bagi para pihak mengenai hak dan kewajibannya, sehingga pemenuhan syarat sahnya suatu perjanjian mutlak untuk dipenuhi.Hal ini kelak apabila dikemudian hari terjadi suatu permasalahan atau sengketa maka penyelesaiannya dapat didasarkan pada perjanjian yang sudah disepakati. ${ }^{1}$

1 Sitompul Asri, Hukum Internet : Pengenalan Mengenai Masalah Hukum Di 
Sedangkan asas kepercayaan di dalam jual beli online para pihak timbul dengan sendirinya dengan menguntungkan satu sama lain dan tidak merugikan satu sama lain. Asas kepercayaan ini sangatlah penting bagi masing-masing kedua belah pihak dalam melakukan transaksi jual beli online melalui media elektronik karena sangat menunjang didalam proses tersebut agar tercipta prestasi yang diinginkan oleh kedua belah pihak dengan memungkinkan komuniaksi global dan memiliki akses terhadap informasi secara luas.

Hal yang menarik untuk melihat bagaimana menampung perikatan yang menggunakan jalur internet atau perdagangan melalui internet.Dalam peraturan mengenai perjanjian atau perdagangan yang ada dalam perundangan lebih fleksibel dalam menghadapi transaksi ecommerce.Sebagaimana dalam perdagangan konvensional, jual beli online melalui media elektronik atau ecommerce menimbulkan perikatan antara pihak untukmemberikan suatu prestasi.Implikasi dari perikatan itu adalah timbulnya hak dan kewajiban

Cyberspace (Bandung : PT.Citra Aditya Bakti, 2001) yang harus dipenuhi oleh pihak yang terlibat.Seiring dengan perkembangan $e$ commerce, semakin bertambah juga permasalahan yang timbul akibat maraknya e-commerce tersebut.Salah satu permasalahan yang timbul yaitu adanya wanprestasi yang dilakukan oleh salah satu pihak yang terlibat dalam ecommerce tersebut.

Salah satu kasus wanprestasi adalah Delta adalah seorang korban wanprestasi online di Bengkulu.Penjual menggunakan website (www.aulaponshop.com) untuk mempromosikan barang-barang elektronik yang mereka jual dengan keterangan yang mereka buat.Delta mentransferkan sejumlah uang untuk membeli sejenis HP tetapi ketika barang sampai maka kondisi barang tidak sesuai dengan spesifikasi yang dituliskan pada keterangan yang dituliskan oleh penjual. Selain Delta, Era Purnamasari juga pernah mengalami kecewa berbelanja Online karena foto barang tidak sesuai dengan barang yang dibeli. ${ }^{2}$.

Adapun rumusan masalah dalam penelitian ini yaitu sebagai berikut:

1. Apakah transaksi jual beli online memenuhi syarat sahnya perjanjian?

kelompokcybercrime116b.wordpress.com 
Tinjauan Yuridis Transaksi Jual beli Online Menurut UU No.11 Tahun 2008

Tentang Informasi dan Transaksi Elektronik di Kota Bengkulu

2. Apakah transaksi jual beli online menurut Undang-Undang No. 11 Tahun 2008 tentang Informasi dan Transaksi Elektronik tidak bertentangan dengan syarat sah suatu perjanjian ?

\section{METODE PENELITIAN}

Jenis penelitian yang digunakan oleh penulis adalah penelitian empiris yang bersifat deskriptif. Penelitian hukum bersifat deskriptif merupakan penelitian yang bertujuan menggambarkan tentang sifat-sifat individu, keadaan, gejala atau kelompok tertentu atau untuk menentukan penyebaran suatu gejala dengan gejala lain dalam masyarakat. ${ }^{3}$

a. Data Primer

Data primer adalah data yang diperoleh langsung dari hasil studi lapangan dengan melakukan wawancara, yaitu kepada 10 orang narasumber yang melakukan jual beli online. Pemilihan 10 orang informan dilakukan karena telah memenuhi data yang diperlukan dalam penelitian dan syarat informan dalam penelitian ini adalah memiliki usia

${ }^{3}$ Amirudin dan Zainal Asikin, Pengantar Metode Penelitiian Hukum, RajaGrafindo Persada, Jakarta, 2004, hlm. 25 minimal 17 tahun dan sudah melakukan transaksi online minimal 2 kali.

\section{b. Data Sekunder}

Data sekunder yaitu data yang mendukung atas permasalahan yang akan dibahas, yaitu kajian pustaka berupa bahan hukum yang penulis peroleh berasal dari :

1) Bahan-bahan hukum primer yang mengikat yang termasuk dalam sumber-sumber hukum transaksi jual beli online ditinjau dari UU Nomor 11 tahun 2008 tentang informasi dan transaksi Elektronik.

2) Bahan hukum sekunder yang memberikan penjelas mengenai bahan hukum primer, yaitu : Buku hukum termasuk skripsi, jurnal hukum, hasil-hasil penelitian, serta makalah.

3) Bahan hukum tersier : Bahanbahan yang memberi petunjuk langsung maupun penjelasan terhadap bahan hukum primer dan sekunder, contohnya kamus bahasa inggris dan kamus hukum. Sesuai dengan judul yang penulis ajukan dan supaya terfokus pada ruang 
lingkup penelitian, sehingga lebih terarah maka untuk memperoleh data yang berkaitan dengan permasalahan yang dibutuhkan dalam penelitian ini maka penulis mengambil transaksi jual beli online di Kota Bengkulu ditinjau dari UU Nomor 11 tahun 2008 tentang informasi dan transaksi Elektronik.

Observasi

Dalam hal ini peneliti akan mengadakan penelitian dengan cara mengumpulkan data secara langsung, melalui pengamatan di lapangan terhadap aktivitas yang akan di lakukan untuk mendapatkan data yang di anggap relevan. Pengukuran observasi menggunakan lembar observasi.

\section{Wawancara}

Dalam hal ini peneliti
mengadakan wawancara secara langsung dengan informan, yaitu orang yang pernah melakukan transaksi jual beli online. Wawancara dalam penelitian ini merupakan wawancara terstruktur, yaitu wawancara yang dilaksanakan secara terencana dengan berpedoman pada daftar pertannyan yang telah dipersiapkan.

\section{Analisis Data}

Analisis data dalam penelitian kualitatif, dilakukan mulai pada saat pengumpulan data berlangsung, dan setelah selesai pengumpulan data dalam periode tertentu.

\section{PEMBAHASAN}

Transaksi Jual Beli Online menurut Undang-Undang No. 11 Tahun 2008 tentang Informasi dan Transaksi Elektronik

Pemanfaatan teknologi informasi dan transaksi elektronik berdasarkan asas kepastian hukum, manfaat, kehatihatian, itikad baik, dan kebebasan memiliki teknologi atau netral teknologi merupakan asas yang terdapt dalam Undang-Undang Nomor 11 tahun 2008 tentang informasi dan Transaksi Elektronik. Hal ini bertujuan dalam pemanfaatan teknologi informasi dan transaksi elektronik agar mencerdaskan kehidupan bangsa sebagai bagian dari masyarakat informasi dunia, mengembangkan perdagangan dan perekonomian nasional dalam rangka meningkatkan kesejahteraan masyarakat.

Berdasarkan hasil penelitian yang telah dilakukan oleh peneliti, hal apa saja yang membuat orang tertarik melakukan transaksi elektronik adalah karena elektronik merupakan kebutuhan yang penting dan banyak kegunaan dari barang elektronik yang mereka beli 
Tinjauan Yuridis Transaksi Jual beli Online Menurut UU No.11 Tahun 2008

Tentang Informasi dan Transaksi Elektronik di Kota Bengkulu

seperti kutipan hasil wawancara kepada informan berikut:

"Saya sering sekali beli barang elektronik karena untuk zaman sekarang itu merupakan kebutuhan primer. Kalau dulu itu merupakan kebutuhan yang bisa diabaikan tetapi sekarang sudah tidak bisa diabaikan lagi"

"barang elektronik itu saya beli karena sangat saya butuhkan, misalnya saya butuh laptop, gadget (smartphone) dan juga barang elektronik lainnya" ${ }^{\prime 4}$

Terdapat informan yang menjadi korban wanprestasi dalam transaksi elektronik.Tetapi informan mengatakan bahwa ia telah tertipu dengan lamanya pengiriman padahal perjanjianpengiriman yaitu 1-2 hari ternyata barang baru sampai setelah satu minggu. Seperti yang dikatakan oleh informan berikut:

"pertama saat pemesanan barang, kita diberikan pilihan untuk menggunakan jasa pengiriman sesuai dengan kebutuhan kita dan upah kirim barang ditentukan oleh lamanya pengiriman. Saat itu saya memilih pengiriman yang paling cepat yaitu satu hingga dua hari tetapi barangnya tiba setelah satu

${ }^{4}$ Dani, 22 tahun, tanggal 3 Agustus 2017 minggu pemesanan dan saya merasa sangat kecewa"15

"sudah sering sekali saya belanja online dan banyak sekali pengalaman saya merasa kecewa karena pelayanan yang kurang memuaskan terutama tentang lamanya pengiriman barang padahal kita sudah menunggu barang yang kira-kira sudah tiba antara dua hingga tiga hari tetapi barangnya tiba satu minggu kemudian, namun ada juga barang yang tiba tepat waktu"6

Berbagai macam jenis produk yang bisa di beli oleh konsumen dalam transaksi jual-beli online.Adapun contohnya adalah, HP, laptop, alat-alat HP, alat-alat laptop, dan juga alat-alat computer.Produk apa saja yang biasa dibeli oleh para informan adalah seperti yang dijelaskan oleh informan berikut:

"macam-macaam baraang yang sering saya beli, tetapi yang sering saya beli yaitu alat-alat elektronik seperti aksesoris handdphone, laptop dan komputer. Saya lebih memilih belanja online karena harganya jauh lebih murah ddan kita tidak perlu lagi langsung datang ke tokonya yang jauh". ${ }^{7}$

Adapun kekurangan transaksi elektronik dibandingkan dengan

${ }^{5}$ Sarah, 22 tahun, tanggal 5 Agustus

${ }^{6}$ Heri, 22 tahun, tanggal 3 Agustus 2017

${ }^{7}$ Ade, 22 tahun, tanggal 5 Agustus 2017 
transaksi langsung menurut para informan adalah jika dilakukan transaksi secara online sering mengecewakan karena barang sering tidak sesuai dengan yang di pesan, spesifikasi barang juga sering menipu, dan konsumen tidak bisa melihat secara langsung kondisi barang yang akan di beli dan jika barang sudah dibeli tidak dapat dikembalikan atau dibatalkan. Sedangkan jika dilakukan transaksi jual beli secara langsung, konsumen dapat secara langsung melihat kondisi barang yang akan dibeli dan tidak akan kecewa dengan kondisi barang yang dibeli karena sudah dilihat secara langsung. Kelebihan konsumen yang sering melakukan transaksi jual beli online adalah harga yang jauh lebih murah jika dilakukan secara online dibandingkan dengan membeli secara langsung seperti yang diakatakan oleh informan berikut:

"kekurangan belanja online menurut saya yaitu sering mengecewakan karena kita tidak bisa melihat langsung barangbarangnya tetapi hanya melihat gambar atau foto serta informasi yang ada tentang barang tersebut. walaupun demikian saya sering belanja online ${ }^{\prime \prime}$

"kelebihan belanja online menurut saya yaitu harga yang jauh lebih murah, tidak perlu menghabiskan banyak tenaga dan waktu cukup dengan melakukan transaksi melalui elektronik dan kita hanya menunggu kurir jasa pemesanana mengantarkan barang yang kita pesan". ${ }^{9}$

Selain itu informan lain juga menjelaskan bahwa kelebihan dari transaksi online adalah prosesnya yang mudah dan menghemat waktu. Berikut penjelasn informan mengenai hal tersebut:

"saya sangat menyukai belanja online karena bisa menghemat biaya, waktu dan tenaga, sedangkan secara konvensional kita harus keliling pasar dan ke toko-toko untuk mendapatkan barang yang kita butuhkan serta menghabiskan biaya, waktu, dan tenaga. Tetapi jika kita belanja secara online kita bisa memilih dan membeli barang hanya dengan melihat gambar memlaui handphone atau laptop, setelah kita menemukan barang yang kita butuhkan maka kita langsung melakukan transaksi dan mentransfer biaya sesuai dengan harga yang telah ditentukan". ${ }^{10}$

Tidak semua produk yang dibeli oleh konsumen sesuai dengan gambar yang tertera.Sering produk yang dibeli tidak sesuai dengan gambar yang tertera

\footnotetext{
${ }^{9}$ Akbar, 23 tahun,7 Agustus 2017

${ }^{10}$ Dimiko, 22 tahun, 7 Agustus 2017
} 
Tinjauan Yuridis Transaksi Jual beli Online Menurut UU No.11 Tahun 2008

Tentang Informasi dan Transaksi Elektronik di Kota Bengkulu

pada media elektronik seperti yang dikatakan oleh informan berikut:

"saya pernah belanja online membeli laptop pada situs belanja online yang saya kunjungi, laptop itu ukurannya kelihatan cukup besar, tetapi ketika saya pesan dan barangnya tiba, ukuran laptop itu kecil dan tidak sesuai dengan gambar. Salahnya saya karena tidak menanyakan ukuran laptop tersebut tetapi hanya menanyakan apakah laptop itu sama sepertipada gambar. ${ }^{\prime 11}$

"gambar pada situs atau web belanja online tidak dapat kita jadikan sebagai patokan, karena barang sering tidak sesuai dengan gambar. Oleh karena itu kita harus cermat dan teliti dalam belanja online dengan melihat spesifikasi barang dan informasi lain yang kita butuhkan ."12

Mengenai undang-undang yang membahas tentang transaksi elektronik, rata-rata informan tidak mengetahui dan tidak memahami Undang-Undang yang membahas tentang transaksi elektronik, sehingga mereka tidak melakukan apaapa ketika mereka merasa kecewa saat melakukan jual beli online seperti yang dikatakan oleh informan berikut:

"kalau soal undang-undang saya kurang paham kak, karea saya

\footnotetext{
${ }^{11}$ Roni, 23 tahun, 7 Agustus 2017
}

${ }^{12}$ Ari, 27 tahun, 7 Agustus 2017 hanya menjalani saja proses belanja online walaupun tidak paham tentang undang-undang belanja online. Apabila saya sudah tertipu maka saya tidak akan belanja lagi disitus ataau web yang sama."13

"saya sama sekali tidak mengetahui undang-undang yang mengatur tentang belanja online. Jika sudah ditipu karena barang tidak dikirim maka saya akan melaporkan ke polisis saja, tetapi jika hanya merasa kecewa dengan kondisi barang dan lamanya pengiriman baraang dimaklumi saja"14

Menurut informan, transaksi jual beli online itu sangat mudah dan tidak ribet. Cukup dengan melihat barang pada gambar dan spesifikasi barang yang akan dibeli, lalu meminta nomor rekening penjual dan pembeli langsung mentrasfer uang sesuai dengan harga dan ongkos kirim dan tinggal menunggu barang yang dibeli dikirim.

"Mudah sekali prosesnya.Itulah sebabnya saya suka sekali belanja online. Cukup mencari di handphone barang yang mau dibeli melihat ketarangannya, lalu kita transfer uang, setelah itu tinggal menunggu barangnya sampai"15

\footnotetext{
${ }^{13}$ Dani, 22 tahun, tanggal 3 Agustus 2017

${ }^{14}$ Sarah, 22 tahun, tanggal 5 Agustus

${ }^{15}$ Heri, 22 tahun, 3 Agustus 2017
} 


\section{P-ISSN : 2599-1892}

Vol. 1, No. 1, Januari 2018

"saya suka sekali belanja online karena tidak repot. Cukup dilakukan diman saja dan ikuti prosesnya, setelah itu kita tinggal menunggu barangnya" ${ }^{\prime 16}$

Menurut informan, tidak ada syarat-syarat tertentu yang harus dilakukan dalam transaksi elektronik karena syarat-syaratnya menurut informan adalah kepercayaan kedua belah pihak dan juga ada pembeli, ada penjual dan ada uang untuk membeli seperti yang dikatakan oleh informan berikut:

"selama saya melakukan transaksi online tidak ada syarat-syarat khusus yang harus dipenuhi. Cukup kepercayaan sajadan ada uang untuk membelinya."17

Menurut informan perkembangan transaksi elektronik di Indonesia sudah sangat pesat.Sebagian besar masyarakat sudah mengenal dan melakukan transaksi jual beli online. $\mathrm{Di}$ semua media sosial sudah menawarkan jual beli secara online seperti yang dikatakan oleh informan berikut:

"zaman sekarang saya rasa jarang sekali orang tidak mengetahui jual beli online, apalagi yang memiliki aplikasi media sosial di handphonenya. Tetapi yang sering melakukan traansaksi online adalah anak muda karena jika orang yang sudah tua mengatakan bahwa jual beli online itu merepotkan"18

"anak muda banyak melakukan transaksi online dibandingkan dengan orang tua. Orang tua lebih memilih untuk belanja secara langsung karena ingin melihat langsung baraang dan spesifikasinya". ${ }^{19}$

Dalam bertansasksi jual beli online, ada jaminan dari pihak penjual apabila terjadi kekeliruan dalam transaksi elektronik seperti jika terjadi kekeliruan dalam pengiriman seperti pemesanan HP merk " $A$ " tetapi yang dikirim adalah HP merk " $B$ ", maka pihak penjual menjamin akan mengganti barang tersebut sesuai dengan perjanjian.

Berdasarkan hasil penelitian dengan melakukan wawancara kepada informan, banyak terjadi wanprestasi, tetapi informan tidak mengetahui tentang aturan hukum yang mengatur tentang transaksi elektronik atau ecommerce dan transaksi elektronik sah menurut hukum apabila memenuhi syarat-sahnya suatu perjanjian dalam pasal 1320 KUHPdt.

\footnotetext{
${ }^{16}$ Ade, 22 tahun, 5 Agustus 2017

${ }^{17}$ Alvin, 26 tahun, 5 Agustus 2017
} 
Tinjauan Yuridis Transaksi Jual beli Online Menurut UU No.11 Tahun 2008

Tentang Informasi dan Transaksi Elektronik di Kota Bengkulu

Dewasa ini, perkembangan perdagangan e-commerce semakin tumbuh dengan pesat. Selain membawa dampak positif bagi perkembangan dan pertumbuhan perekonomian Indonesia juga akan menimbulkan permasalahanpersamalahan yang tentunya harus ditemukan cara penyelesaiannya menggunakan peraturan perundangundangan yang berlaku di Indonesia. Bagi masyarakat Indonesia hal ini terkait masalah hukum yang sangat penting.Pentingnya permasalahan hukum di bidang E-Commerce adalah terutama dalam memberikan perlindungan terhadap para pihak yang melakukan transaksi melalui internet.

Mengingat pentingnya hal tersebut maka Indonesia pada tahun 2008 lalu mengeluarkan peraturan khusus yang mengatur transaksi melalui internet yaitu Undang-Undang Nomor 11 tahun 2008 tentang Informasi dan Transaksi Elektronik yang untuk selanjutnya disingkat Undang-Undang ITE. Dalam upaya menyikapi perkembangan hukum terkait dengan jual-beli melalui internet, Pemerintah telah mengeluarkan Undang-Undang Nomor 11 Tahun 2008 tentang Informasi danTransaksi Elektronik, menimbang bahwa pembangunan nasional adalah suatu proses yang berkelanjutan yang harus senantiasa tanggap terhadap berbagai dinamika yang terjadi di masyarakat.

Dalam Pasal 1 butir 2 UndangUndang ITE, disebutkan bahwa transaksi elektronik adalah perbuatan hukum yang dilakukan dengan mengunakan komputer, jaringan komputer atau media elektronik lainnya. Transaksi jual beli secara elektronik merupakan salah satu perwujudan ketentuan tersebut. Kontrak elektronik dalam transaksi elektronik, harus memiliki kekuatan hukum yang sama dengan kontrakkonvensional. Transaksi elektronik yang melibatkan para pihak dari dalam negeri yaitu Negara Indonesia, tidaklah sulit untuk menetapkan aturan hukum yang berlaku apabila terjadi masalah.Secara otomatis the applicable law-nya adalah hukum Indonesia, sehingga baik Burgelijk Wetboek maupun Undang-Undang.

Pelaku usaha yang menawarkkan produknya kepada calon konsumen hendaknya membuat data-data atau informasi yang benar dan tepat serta selalu di perbaharui jika ada perubahan, sehingga konsumen mendapat kepastian lokasi, jenis, dan siapa pelaku usaha tersebut. Terutama dalam transaksi 
elektronik sehingga terciptanya kontrak elektronik yakni perjanjian para pihak yang dibuat melalui system elektronik.

Dengan demikian dalam kegiatan transaksi perdagangan melalui internet diperlukan adanya suatu kepastian hukum yang bisa menjamin traksaksi jual beli terhadap pelaku usaha kepada pembeli sehingga tidak ada pihak-pihak yang merasa dirugikan. Dalam hal ini pihak pelaku usaha menjelaskan terlebih dahulu akan barang atau produk yang akan dijual melalui internet berdasarkan Undang-Undang Nomor 11 Tahun 2008tentang Informasi dan Transaksi Elektronik pasal 9 bahwa"pelaku usaha yang menawarkan produk melalui system elektronik harus menyediakan informasi yang lengkap dan benar berkaitan dengan syarat kontrak, produsen dan produk yang ditawarkan. Sehingga jelas pelaku usaha saat menawarkan produk yang ditawarkan untuk dibeli melalui internet harus menjelaskan usaha, alamat, dan informasi yang baik dan benar."

Perlindungan Konsumen dapat diterapkan untuk menyelesaikan sengketa yang timbul. Namun bagi transaksi perdagangan lintas negara bukan Negara Indonesia, penyelesaian sengketa akan dilakukan oleh forum yang dipilih oleh para pihak dengan menggunakan hukum yang telah dipilih pula oleh para pihak dalam kontrak elektronik, sebagaimana telah dijelaskan di atas dalam pembahasan tentang pilihan hukum dan pilihan forum.

Dalam Pasal 38 Undang-Undang No. 11 Tahun 2008 tentang Informasi dan Transaksi Elektronik sendiri menegaskan bahwa "Setiap orang dapat mengajukan gugatan terhadap pihak yang menyelenggarakan Sistem Elektronik dan/atau menggunakan Teknologi Informasi yang menimbulkan kerugian".Menurut pasal ini, masyarakat dapat mengajukan gugatan secara perwakilan terhadap pihak yang menyelenggarakan Sistem Elektronik dan/atau menggunakan Teknologi Informasi yang berakibat merugikan masyarakat, sesuai dengan ketentuan Peraturan Perundang-undangan.Lebih lanjut Pasal 39 Undang-Undang No. 11 Tahun 2008 tentang Informasi dan Transaksi Elektronik menjelaskan bahwa:

"Gugatan perdata dilakukan sesuai denganketentuan Peraturan Perundang-undangan. Selain penyelesaian secara gugatan perdata,para pihak juga dapat menyelesaikansengketa melalui arbitrase, atau lembagapenyelesaian 
Tinjauan Yuridis Transaksi Jual beli Online Menurut UU No.11 Tahun 2008

Tentang Informasi dan Transaksi Elektronik di Kota Bengkulu

sengketa alternatif lainnyasesuai dengan ketentuan

undangan."

PeraturanPerundang-

Transaksi jual beli, meskipun dilakukan secara online, berdasarkanNo. 11 Tahun 2008 tentang ITE tetap diakuisebagai transaksi elektronik yang dapat dipertanggungjawabkan. Kontrak Elektronik itu sendirimenurut Pasal 48 ayat (3) Undang-Undang ITEsetidaknya harus memuat hal-hal sebagai berikut; data identitas parapihak; objek dan spesifikasi; persyaratan Transaksi Elektronik; harga dan biaya; prosedur dalam halterdapat pembatalan oleh para pihak;ketentuan yang memberikan hakkepada pihak yang dirugikan untukdapat mengembalikan barangdan/atau meminta penggantian produk jika terdapat cacatter sembunyi; dan pilihan hukum penyelesaian transaksi Elektronik. Dengan demikian, padatransaksi elektronik yang terjadidikasus dapat menggunakan instrumen Undang-Undang ITE sebagai dasar hukum dalam menyelesaikan permasalahannya.

Terkait dengan perlindungan konsumen, Pasal 49 ;

- Ayat (1) Undang-Undang ITE menegaskan bahwa Pelaku Usahayang menawarkan produk
melaluiSistem Elektronik wajibmenyediakan informasi yang lengkapdan benar berkaitan dengan syaratkontrak, produsen, dan produk yangditawarkan. Pada ayat berikutnyalebih ditegaskan lagi bahwa PelakuUsaha wajib memberikan kejelasaninformasi tentang penawaran kontrak atau iklan. Lalu muncul pertanyaanbahwa bagaimana jika barang bagipihak konsumen tidak sesuai denganyang diperjanjikan?

Ayat (3) Undang-Undang ITE mengatur khusus tentang hal tersebut,yakni Pelaku Usaha wajibmemberikan batas waktu kepadakonsumen untuk mengembalikanbarang yang dikirim apabila tidaksesuai dengan perjanjian atau terdapatcacat tersembunyi.Selain keduaketentuan tersebut di atas, apabilaternyata barang yang diterima tidaksesuai dengan foto pada iklan tokoonline tersebut (sebagai bentukpenawaran), kita juga dapatmenggugat Pelaku Usaha (dalam halini adalah penjual) secara perdatadengan dalih terjadinya wanpretasiatas transaksi jual beli yang Anda lakukan dengan penjual. 
Menurut Prof. R. Subekti, remedyyang tepat, murah dan efektif S.H.dalam bukunya tentang "Hukum sertamengurangi penentuan perkara Perjanjian", wanprestasi adalahkelalaian dinegara asing. Ada atau kealpaan yang dapatberupa 4 beberapakeuntungan bagi pembeli dan macam kondisi yaitu:

a. Tidak melakukan apa yang disanggupi akan dilakukannya

b. Melaksanakan apa yang dijanjikannya, tetapi tidaksebagaimana dijanjikan

c. Melakukan apa yangdijanjikannya, tetapi terlambat

d. Melakukan sesuatu yangmenurut perjanjian tidak bolehdilakukannya.

\begin{tabular}{lrr}
\multicolumn{1}{c}{ Jika salah } & satu & dari 4 \\
macamkondisi & tersebut & terjadi, \\
makasecara & perdata & dapat
\end{tabular}
menggugatpenjual online dengan dalih terjadiwanprestasi (misalnya, barang yangditerima tidak sesuai dengan spesifikasi barang yang dimuat dalam gambar).

Penyelesaian sengketa ECommerce internasionaldimungkinkan untuk diselesaikanterutama yang meliputi sengketa bernilai kecil dalam forum yang tepat,yaitu dengan Resolusi Sengketa secara Online (ODR), atau APS onlineyang menjadi cara praktis untukmemberi para pelanggan pelakuusaha trnsaksi E-Commerce dalam penyelesaian sengketa melalui ODRantara lain:

1. Penghematan waktudan uang. Keuntungan ini karena parapihak tidak perlu membayar biayayang harus dikeluarkan untukmenghadiri persidangan dan biaya-biayayang berkaitan dengan hal itu.Kecepatan ODR adalah salah satukeuntungan dasarnya, pihak-pihakdan pihak netral tidak perlumelakukan perjalanan untuk bertemu,mereka tidak perlu ada di waktu yangsama, jangka waktu antarapenyerahan dapat singkat,penyelesaian dapat berdasarkandokumen saja.

2. biasanya biaya layananpenyelesaian sengketa perdata adalahgabungan dari biaya institusipenyelesaian sengketa, fee, dan biayapihak netral, biaya para pihak, ongkoshukum. Dalam ODR beberapa biayaini tidak ada atau berkurangsignifikan. 
Tinjauan Yuridis Transaksi Jual beli Online Menurut UU No.11 Tahun 2008

Tentang Informasi dan Transaksi Elektronik di Kota Bengkulu

3. pihak yangmenggunakan akses internet lebihyakin dalam menghadapi proses yangakan dijalaninya, sebab mereka dapatdengan mudah mengontrol danmerespon apa yang terjadi dalamproses.

4. jika para pihakenggan melakukan tatap muka, dapatmenghindari pertemuan dengan pihaklawannya. Para pihak dapatmenghindarkan diri perasaan takutakan diintimidasi dalam proses. Hal ini merupakan persoalan psikologis.

Berdasarkan pada penyelesaiansengketa alternatif secara offline atautradisional, maka dapat dibagi jugabentuk penyelesaian sengketa dengancara online (ODR) yang dapatdilakukan melalui Arbitrase Online.

Perkembangan teknologi yang memungkinkan terjadinya perdagangan secara elektronik, telah mengilhami dilakukan penyelesaian sengketa secara elektronik pula. Ditengah kegalauan sistem hukum yang tidak mengikuti perkembangan zaman dan cepatnya kemajuan tekhnologi, tekhnologi telah menggoreskan gagasan tentang penyelesaian sengketa secara online,dalam bentuk arbitrase onlien (EArbitration).

Arbitrase online menjadi suatupilihan menarik dalam penyelesaian sengketa E-Commerce. Karaktersitik transaksi di internet merupakan transaksi lintas batas geografis yang menghubungkan antara konsumen dengan pelaku usaha dari berbagai negara yang dapat melahirkan sengketa.

Sengketa tersebut nilai nominalnya sebahagian sangat kecil, tetapi membutuhkan penyelesaian yang cepat, dan dengan biaya yang tidak terlalu mahal. Berbagai upaya yang telah dilakukan diantaranya dengan menyediakan alternatif Penyelesaian Sengketa secara online, seperti arbitrase online.

\section{PENUTUP}

\section{Kesimpulan}

Berdasarkan hasil pembahasan mengenai kepastian hukum transaksi elektronik di internet berdasarkan UndangUndang No. 11 tahun 2008 tentang informasi dan transaksi elektronik bahwa:

1. Syarat sah transaksi berdasarkan Pasal 2 Undang-Undang Nomor 11 Tahun 2008 tentang Informasi dan Transksi Elektronik ("UU ITE"). Berdasarkan ketentuan ini, anak-anak 


\section{P-ISSN : 2599-1892}

Vol. 1, No. 1, Januari 2018

yang masih di bawah umur dapat melakukan E-Commerce dan tidak memenuhi syarat subjektif dalam Pasal 1320 KUHPerdata. Oleh karena itu, kontrak dapat dibatalkan melalui seseorang yang mengajukan pembatalan di pengadilan. Adapun syarat umur yang melakukan perjanjian adalah telah berumur 21 tahun menurut pasal 330 KUHPdt.

2. Transaksi jual beli online menurut Undang-Undang No. 11 Tahun 2008 tentang Informasi dan Transaksi Elektronik tidak bertentangan dengan syarat sah suatu perjanjian dalam Pasal 1320 KUHPdt.

\section{Saran}

1. Hendaknya pemerintah melakukan penyuluhan ke desa maupun kota tentang cara bertransaksi yang baik dan benar sesuai dengan perundangundangan yang berlaku sehingga memberikan kepastian hukum ketika perkara dalam persidangan.

2. Hendaknya konsumen yang ketika bertransaksi mengalami kerugian menempuh jalur hukum jika tidak ada itikad baik dari produsen

3. Masyarakat dapat berperan meningkatkan pemanfaatan teknologi informasi melalui penggunaan dan penyelenggaraan system elektronik dan transaksi elektronik sesuai dengan ketentuan Undang-undang Nomor 11 tahun 2008 tentang informasi dan transaksi elektronik

\section{DAFTAR PUSTAKA}

\section{Buku}

Abdurrahman, 2008.Syeh dkk. Fiqh Jual Beli. Jakarta: Senayan Publishing

Ali Hasan, 2003. Berbagai Macam Transaksi Dalam Islam (Fiqh Muamalah), Jakarta: PT Raja Grafindo Persada

Asnawi, Haris Faulidi, 2004. Transaksi Bisnis e-commerce Perspektif Islam. Yogyakarta: Magistra Insania Press

Darma, Jarot S, 2009. Shenia A, Buku Pintar Menguasai Internet. Bandung: Alfabeta

Febrian, Jack, 2001. Menggunakan Internet, Bandung: CV. Informatika

Sitompul Asri, 2001. Hukum Internet: Pengenalan Mengenai Masalah Hukum Di Cyberspace. Bandung : PT.Citra Aditya Bakti

Sujarweni, V. Wiratna. 2014. Metode Penelitian: Lengkap, Praktis, dan Mudah Dipahami. Yogyakarta: Pustaka Baru Press 
Tinjauan Yuridis Transaksi Jual beli Online Menurut UU No.11 Tahun 2008

Tentang Informasi dan Transaksi Elektronik di Kota Bengkulu

Syamsuri, 2005.Pendidikan Agama Islam.Erlangga, Jakarta

Tim Litbang Wahan Komputer, 2001. Apa dan bagaimana E-commerce. Yogyakarta: Andi

Umiyati, Tinjauan Hukum Islam Terhadap Akad Pesan Barang (Studi Kasus Di Toko Mebel Mia Jaya Abadi kec. Tahunan kab. Jepara), Mu'amalah, 2008)

\section{Jurnal}

Kuspraningrum, Emilda, Keabsahan Kontrak Elektronik dalam UU ITE ditinjau dari pasal 1320 KUHPerdata dan UNICITRAL Model Law On Electronik Commerce (Jurnal Vol.7 No.2, Fakultas Hukum Mulawarman Samarinda, 2011)

\section{Undang-Undang}

Undang-Undang Nomor 11 Tahun 2008 tentang Informasi dan Transaksi Elektronik Pasal 1 Angka 2 